\title{
El sindicalismo en MéXico \\ A través de la lente de Aurelio Escobar
}

Ana Lilia Quintero Barajas*

\section{Resumen}

El fotógrafo Aurelio Escobar Castellanos capturó con su cámara múltiples aspectos de la evolución de la ciudad de México y de sus habitantes. Se especializó en el uso de la cámara rotativa Cirkut, la cual permitía conseguir imágenes panorámicas con una perspectiva de hasta $360^{\circ}$ y obtener negativos de más de dos metros de longitud. La maestría que logró en la fotografía panorámica lo llevó a ser reconocido por múltiples e importantes instituciones de nuestro país, sobre todo por un sinnúmero de sindicatos con los cuales estuvo comprometido a lo largo de su vida y su labor como fotógrafo, por lo que sus imágenes son un testimonio invaluable para la investigación y comprensión del sindicalismo en nuestro país.

Palabras clave: fotógrafo, sindicalismo, panorámicas.

\begin{abstract}
The photographer Aurelio Escobar Castellanos captured with his camera several aspects of Mexico City and its people evolution. He specialize in the use of the rotative camera "Cirkut" which allowed you to take panoramic images with a $360^{\circ}$ perspective and to get negatives of more than two meters long. The mastery he achieved in panoramic photography lead him to be recognized by multiple and important institutions of our country, mostly of several unions which he was commited to during his whole life as a photographer, which is why his images are invaluable testimony for the investigation and understanding of the syndicalism in our country.
\end{abstract}

Keywords: Photographer, Syndicalism, Panoramic.

* AGN-DAHC- Fototeca. 


\section{Introducción}

Dentro del universo de información que la Fototeca del Archivo General de la Nación posee y pone a disposición de los investigadores se encuentra una de las colecciones fotográficas más importantes y representativas de su acervo: el fondo Aurelio Escobar Castellanos (en adelante $A E C$ ), que cuenta con 4,369 imágenes, de las cuales más de tres mil son negativos panorámicos de gran formato y constituyen una de las colecciones más grandes a nivel nacional de este tipo de material fotográfico de carácter histórico.

Aurelio Escobar capturó con su cámara, como fotógrafo independiente, múltiples aspectos de la evolución de la ciudad de México y de sus habitantes, pero sobre todo, de un sinnúmero de sindicatos y sus actividades a lo largo de más de cuarenta años.

El movimiento sindicalista buscó el aumento económico, laboral, social e intelectual de la clase obrera mediante organizaciones de combate y posteriormente corporativistas, con las cuales Aurelio Escobar estuvo comprometido a lo largo de su vida y su labor como fotógrafo, por lo cual sus imágenes son un testimonio invaluable para la investigación y comprensión del sindicalismo en nuestro país.

El presente trabajo aborda brevemente la vida de Aurelio Escobar y su labor como fotógrafo de la Revolución, su especialización en la fotografía panorámica y, por último, ofrece una visión general sobre la evolución del sindicalismo en México a través de las imágenes capturadas por su cámara, hasta el surgimiento del llamado "charrismo" sindical. Esta investigación busca difundir la obra de Escobar entre los investigadores interesados en la utilización de la imagen como documento histórico.

\section{Aurelio Escobar Castellanos}

Nació en Zacoalco de Torres, Jalisco, el 8 de noviembre de 1888, hijo de José Benito Escobar Ureña y Josefa Castellanos. En 1906, junto con sus hermanos Enrique, Ignacio, Beatriz, Domitila e Isabel llegó a la ciudad de México bajo la protección de su sobrino, el acreditado fotógrafo Heliodoro Juan Gutiérrez Escobar, con quien colaboró activamente en todas sus empresas fotográficas durante 28 años. Los estudios fotográficos 


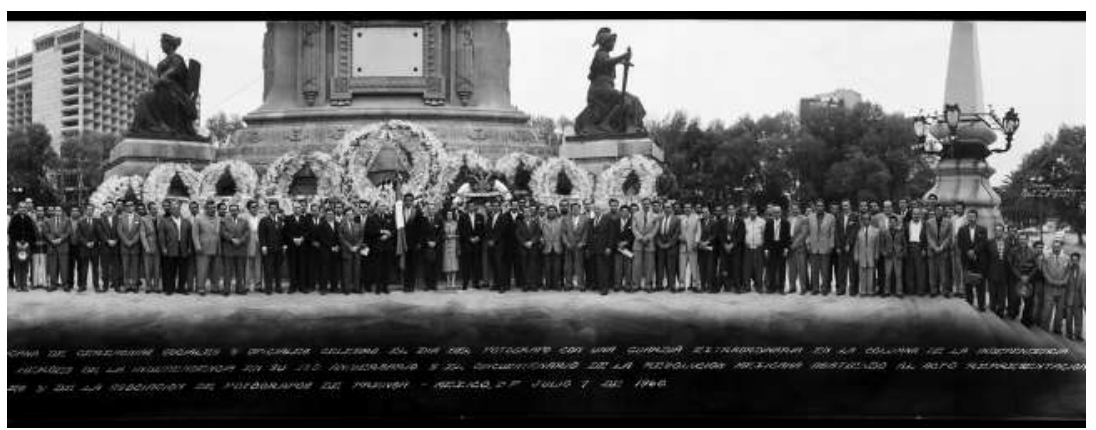

"Panorámica de la Unión de Fotógrafos de la República Mexicana de Ceremonias sociales y oficiales, el día del fotógrafo. Columna de la Independencia", 7 de julio de 1960, AGN, AEC/27/025 (2600).

propiedad de Gutiérrez en los que Aurelio Escobar colaboró fueron La casa amplificadora de retratos (1905), Postal Photo Finishing (1906), Fotografía Marst (1911-1928) y Foto París (1932). ${ }^{1}$

Escobar proporcionó evidencia visual del conflicto revolucionario dentro del movimiento maderista y, posteriormente, de la llamada Decena Trágica, forjándose como fotorreportero.

En junio de 1912 realizó estudios en la Souther School of Photography, en McMinnville, Tennessee, los cuales concluyó en 1913, cuando ganó el premio a la mejor exhibición fotográfica en la Feria Estatal de South Carolina. Se estableció en la ciudad de Columbia South Carolina, donde trabajó en el estudio fotográfico Lyles, al tiempo que lo hacía en México de 1914 a 1919. En 1918 adquirió el estudio fotográfico Hennies en la misma ciudad.

Durante sus viajes periódicos realizados entre México y Estados Unidos introdujo en nuestro país la fotografía panorámica y el uso comercial de la cámara rotativa Cirkut. Sus primeras fotografías panorámicas fueron firmadas por H.J. Gutiérrez, Foto Marst, Foto París, algunas por la Compañía Industrial Fotográfica (CIF) y Vicente Cortés Sotelo; posteriormente aparecería la firma A. Escobar como fotógrafo independiente.

1 Guevara Escobar, "H. J. Gutiérrez, Foto", en Fotógrafos de la revolución, (http:// fotografosdelarevolución.blogspot.mx/2010/11/h-j-gutiérrez-foto.html), [consulta 19 de septiembre de 2012]. 
A partir de 1925 radicó permanentemente en México. Contrajo matrimonio el 22 de abril de 1934 con María del Consuelo Vélez de la Torre, con quien procreó a María Josefina Escobar Vélez, hija única del matrimonio.

A. Escobar Fotógrafo Profesional fue su primer estudio fotográfico en México; lo abrió en el mismo lugar que ocupaba Foto París: avenida 16 de septiembre número 64, en el centro histórico de la ciudad de México.

Con la ayuda de sus hermanos trabajó ininterrumpidamente hasta su muerte, ocurrida el 11 de febrero de 1964 a consecuencia de un accidente de tránsito. Enrique, su hermano, permaneció a cargo del estudio, para entonces llamado Fotopanorámicas Escobar, conservando la misma línea de trabajo hasta 1979, cuando cerró definitivamente. ${ }^{2}$

\section{Aurelio Escobar y la Revolución}

Justo cuando Aurelio Escobar cumplió 22 años estalló el primer conflicto bélico documentado por la fotografía en México: la Revolución. Como muchos otros fotógrafos de estudio, salió a las calles a documentar gráficamente el "grito" revolucionario que lo envolvía todo y cuya labor, seguramente, era mucho mejor pagada que el retrato de gabinete, el cual que ya nadie buscaba. ${ }^{3}$

Así incursionó como reportero gráfico y logró fotografías sin crédito autoral, firmadas bajo la Agencia H. J. Gutiérrez, que años después se volverían icónicas del movimiento armado revolucionario. Dichas imágenes fueron impresas en su mayoría como "tarjetas postales", debido a la popularidad y difusión que tuvo este formato en nuestro país desde el siglo XIX. Las postales permitieron la comunicación epistolar "económica" entre dos personas separadas geográficamente, mediante el intercambio de mensajes cortos e imágenes que de alguna manera ilustraran la realidad que se quería transmitir al destinatario, ya fuera hermosa, si se trataba de

2 Escobar Castellanos en http://es.wikipedia.org/wiki/Aurelio_Escobar_Castellanos, [consulta 19 de octubre de 2011]. Debido a la falta de bibliografía sobre la vida de Aurelio Escobar Castellanos se tuvo que recurrir a los artículos disponibles en línea.

3 Ezequiel Carrasco, Entre los nitratos de plata y las balas de bronce, p. 27. 
un paseo, o una realidad bélica como la padecida en nuestro país en ese momento. ${ }^{4}$

El avance tecnológico en la fotografía permitió la impresión masiva de las imágenes captadas por los fotógrafos como testimonios fidedignos y tangibles de una realidad con la cual los grabados, litografías e impresiones ya no pudieron competir.

Las imágenes de las batallas y caudillos revolucionarios se popularizaron y comenzaron a venderse en serie a un público ávido de noticias, por ello constituyeron para los fotógrafos de esta época el principal medio de subsistencia y la forma de difundir su obra. Dicho auge permitió también el surgimiento y mantenimiento de casas editoras como para la que trabajó por años Escobar.

Cámara en mano, dio evidencia visual del desarrollo del conflicto armado, pues cubrió cotidianamente diferentes frentes de guerra, entre ellos el desarrollo del movimiento maderista y, posteriormente, la Decena Trágica, la toma de Casas Grandes, Chihuahua, entre muchos otros.

\section{Fotografía panorámica}

Aurelio Escobar se especializó en el uso de la cámara rotativa Cirkut, la cual permitía conseguir imágenes con una perspectiva de hasta $360^{\circ}$ y obtener negativos de más de dos metros de longitud; este tipo de fotografía no se utilizaba de forma cotidiana en nuestro país, tal vez por lo complicado de las tomas, el revelado, la dificultad para organizar y encuadrar a las personas que serían fotografiadas, etcétera. Sin duda Escobar no fue el único fotógrafo en utilizar este tipo de fotografía, pero sí fue un especialista en este género, el cual explotó durante más de cuarenta años, y que, a su muerte en 1964, seguiría utilizando su familia.

La fotografía panorámica caracterizó a Aurelio Escobar, pues aunque dominó el retrato de gabinete, luego la fotografía de prensa y el retrato de estudio, fue en aquélla donde mejor desarrolló sus habilidades y estilo personal; por ello su estudio adquirió el nombre de Panorámicas Escobar y, posteriormente, Fotopanorámicas Escobar.

4 Charles B. Waite, La Época de Oro de las Postales en México, pp. 7-19. 


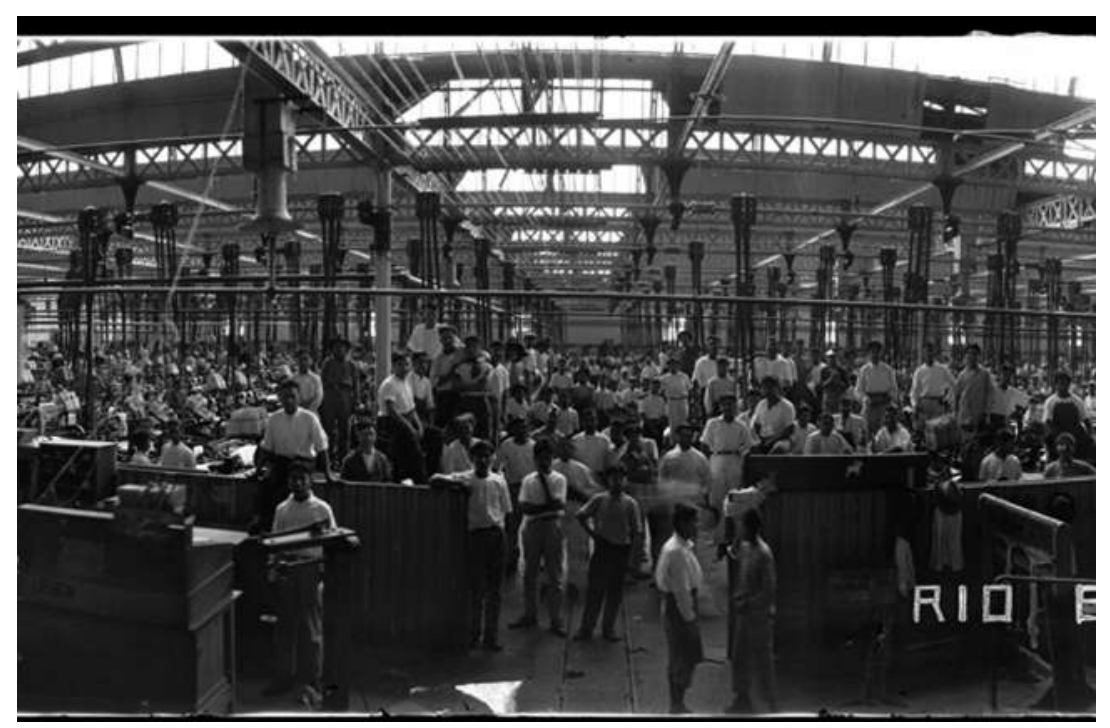

"Panorámica de fábrica de obreros en Rio Blanco Veracruz", abril 1926. (Detalle). AGN, AEC/17/001 (1906). El Valle de Orizaba fue una de las regiones con mayor efervescencia sindical, en respuesta a la represión de que fueron víctima los obreros textiles durante el maderismo. Las fábricas de Rio Blanco, Veracruz padecieron esta represión en 1907 y 1912.

La maestría lograda en la fotografía panorámica lo llevó a ser reconocido por múltiples personas e importantes instituciones de nuestro país que requirieron sus servicios continuamente, entre ellas varias generaciones de egresados de la Universidad Nacional Autónoma de México; escuelas como el Colegio Gordon, Cervantes y Williams; innumerables plantillas de médicos residentes del Hospital General, el Instituto Mexicano del Seguro Social (IMSS) y el Instituto de Seguridad Social al Servicio de los Trabajadores del Estado (ISSSTE); trabajadores de la Lotería Nacional; las fotografías anuales de los empleados de empresas como Fábrica Santa Rosa o Colgate Palmolive; las reuniones anuales de los Clubes de Leones; la fábrica La Escocia, por el fallecimiento de Martín Torres Padilla; y la concentración anual Evangélica en el Hemiciclo a Juárez, por citar algunos de sus clientes. Aurelio Escobar también fue contratado por presidentes y gobernadores de algunos estados de la república para cubrir los eventos políticos que llevaban a cabo, pues su fotografía también sirvió en numerosas ocasiones para este tipo de discurso. Sobre todo los principales sindicatos mexicanos 
requirieron sus servicios, predominando esta acepción en su trabajo, seguramente al sentirse más cómodo con ella.

La fotografía panorámica respondió a una época en que la masa, el contingente y el compañerismo lo eran todo, y las imágenes debían captarlo así: "a todos juntos".

\section{El anarquismo y las sociedades mutualistas}

Los últimos veinte años del siglo XIX estuvieron marcados por la formulación y puesta en práctica de diferentes corrientes ideológicas que cuestionaron el pensamiento político y social de Europa y Estados Unidos. Una de ellas fue el anarquismo, cuya variante conocida como "anarcosindicalismo" o "sindicalismo revolucionario" sostenía que en la organización de la clase obrera estaba la base del cambio social. ${ }^{5}$

El anarquismo ofrecía al pueblo las bases ideológicas para su emancipación, y el sindicalismo promovía la "acción directa", colectiva, lo que les permitió a los trabajadores estar en mayor contacto con la realidad y difundir los fundamentos del anarquismo de forma práctica.

La influencia ideológica más importante para el sistema obrero nacional fue, sin duda, la difundida por los anarquistas españoles exiliados en México, quienes trabajaron incansablemente para crear la conciencia colectiva de los trabajadores mexicanos. Las condiciones deplorables de vida que sufrieron los campesinos obligaron a gran cantidad de ellos a salir de sus lugares de origen y establecerse en las ciudades, buscando trabajo en fábricas o dependencias y soportando situaciones laborales lamentables en todos los sentidos, que la creciente industrialización porfirista nunca "consideró" necesario remediar. ${ }^{6}$

Unas de las primeras organizaciones obreras formadas en México fueron las llamadas "organizaciones de resistencia" o "sociedades mutualistas", impulsadas desde 1865 en nuestro país por el griego Plotino Rhodakanaty. Estas sociedades cubrieron necesidades históricamente antagónicas, es

5 Ribera Carbó, Anna, La Casa del Obrero Mundial: Anarcosindicalismo y Revolución en México, p. 29. 6 Ruth Clark, Marjorie, La organización obrera en México, p. 12. 
decir, tanto del gobierno como de la incipiente clase obrera. Por una parte, debían organizar a los obreros en cajas de ahorro y colectas para apoyarse "mutuamente" en eventos catastróficos, enfermedades o muerte, como un intento para mejorarles la vida; por otra parte, el gobierno vio en ellas una excelente forma de controlar a los trabajadores y las usó como una válvula de escape controlada a la crítica o sublevación organizada, control que le sirvió durante muchos años. ${ }^{7}$

Este tipo de asociaciones corporativas sembró la semilla que a la larga permitiría la concientización del trabajador y la lucha por la transformación social ya organizada en sindicatos. Aurelio Escobar capturó con su lente algunas de estas sociedades precursoras del sindicalismo que al paso del tiempo seguirían existiendo. Una de ellas fue la Sociedad Mutualista de Despachadores y Telegrafistas Ferrocarrileros, sucesora de la primera sociedad mutualista de ferrocarrileros, uno de los sindicatos más organizados y combativos de nuestro país. ${ }^{8}$

\section{La Casa del Obrero Mundial (сом)}

Escobar viajó a Estados Unidos en 1912 para realizar estudios como fotógrafo. Fue miembro activo de varios sindicatos y sociedades mutualistas de fotógrafos, por lo tanto, sería falso pensar que permaneció ajeno a la labor realizada por la COM, fundada en 1912 por los miembros del grupo anarquista Luz.?

La COM buscó desde sus orígenes divulgar y apoyar el sindicalismo revolucionario entre los trabajadores, como medio de defensa contra los patrones y dueños de fábricas y empresas. ${ }^{10}$

\section{7 Ídem.}

8 AGN, AEC/01/024. En 1926 Aurelio Escobar perteneció a la Asociación de Fotógrafos de México. Sociedad Mutualista.

9 Ribera Carbó, op. cit. p. 40.

10 Ibíd., pp. 41-42. La finalidad del grupo anarquista Luz era publicar un periódico para la difusión del anarquismo y difundir en México la escuela racionalista, inspirada en la Escuela Moderna del español Francisco Ferrer Guardia, cuya ideología se sintetizó en seis ideas básicas: Coeducación de ambos sexos y diferentes clases sociales, laicismo y racionalismo, antiautoritarismo y educación integral. 

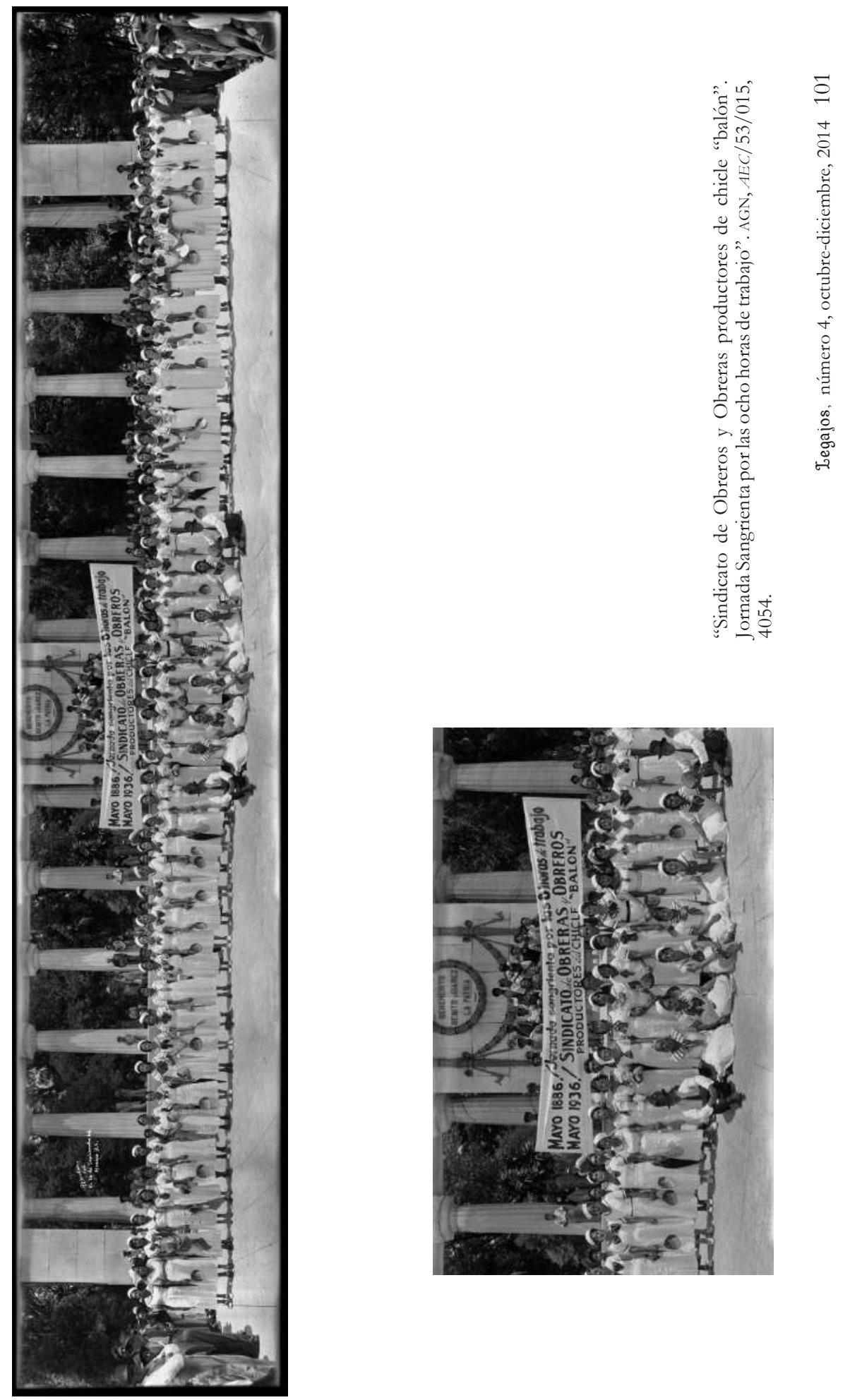
Si bien la COM no fue un sindicato, sí fue el referente en la organización de la lucha obrera, orientando y logrando el tránsito de las sociedades mutualistas al sindicalismo. ${ }^{11}$

En sus inicios, la COM apoyó la denominada "acción directa", es decir, el no vincularse con el Estado por medio de alianzas o partidos políticos y actuar sólo a través de la organización obrera, por medio de huelgas, boicots, paros, etcétera.

A partir de 1913 las demandas sobre los salarios, la seguridad en el trabajo $y$, particularmente, la jornada laboral de ocho horas fueron necesidades universales en la mente de los trabajadores mexicanos, gracias a la labor de orientación de la COM. Esta lucha por los derechos laborales se observa bien entrado el siglo xx (1936) y es ilustrada por una de las fotografías más dramáticas de Aurelio Escobar, la cual nos habla de la "Jornada sangrienta" padecida por los trabajadores afiliados al Sindicato de Productores de Chicle Balón para lograr la jornada laboral de ocho horas.

Posteriormente, buscaron el favor de la clase política para el apoyo del proletariado, consideraron necesario aliarse con el Ejército Constitucionalista, liderado por Álvaro Obregón, y crearon los llamados batallones rojos.

Los batallones rojos fueron utilizados por los constitucionalistas como una legitimización de sus objetivos políticos en cuanto al proletariado. Se les empleó como manifestación de propaganda y le confirieron un carácter de "organización de masas" a una fuerza de choque financiada por el Estado. Fueron los únicos contingentes de obreros adiestrados y uniformados militarmente que han participado en la lucha armada al lado del ejército mexicano. ${ }^{12}$

Posteriormente, esta fórmula de agrupaciones de obreros militarizados a favor del Estado se utilizó — y aún se utiliza - en el sindicalismo mexicano; ejemplo de ello lo tenemos en una de las imágenes de Aurelio Escobar, donde se observa la "Ceremonia con motivo de la entrega de banderas a los representantes de las milicias obreras por el secretario de la Defensa Nacional, noviembre de $1939 .{ }^{13}$

11 Ibid., p. 53.

12 Ribera Carbó, op. cit., p. 149.

13 AGN, AEC/06/025, 1318. 


\section{CROM}

En mayo de 1918 se creó la Confederación Regional Obrera Mexicana (CROM), en un congreso celebrado en Saltillo, Coahuila, luego de varios intentos fallidos por crear una organización central que agrupara a todos los sindicatos independientes y les permitiera lograr una fuerza representativa del movimiento sindical. ${ }^{14}$

Este congreso, organizado y auspiciado por Venustiano Carranza, tenía la intención de devolver al Estado el control sobre la clase obrera, perdido con el cierre de la COM; dicho plan falló cuando el control sobre los trabajadores cayó en manos del dirigente sindical Luis N. Morones. ${ }^{15}$

La CROM fue dirigida desde un principio por el grupo Acción, creado y presidido a partir de 1918 por el antes mencionado Morones, cuyos integrantes organizaron y controlaron arbitrariamente la mayoría de los sindicatos del país. ${ }^{16}$ Desde el inicio de la vida activa de la CROM, su objetivo fue establecer relaciones con el gobierno y lograr puestos importantes para sus dirigentes, con la falsa justificación de que, si el movimiento sindical quería progresar, debía hacerlo por medio de la acción política para, posteriormente, lograr un cambio a fondo en la estructura social — cambio que en la práctica jamás se buscó.

Durante la década de los veinte, la CROM logró una "unidad obrera" permanente a través del control ejercido sobre los sindicatos de obreros de todas las tendencias imaginables, por medio de amenazas o buscando su destrucción en caso de que se negaran a pertenecer, afiliarse a la CROM o apoyar al Partido Laborista. ${ }^{17}$

En 1926, diversas organizaciones sindicales comenzaron a retirarse definitivamente de la CROM tan pronto se suscitó la ruptura con Obregón. El Partido Laborista también le retiró su apoyo al resultar evidente su reelección a la presidencia y, sobre todo, porque no podían esperar ningún favoritismo si llegaba a reelegirse, como era lo más probable. ${ }^{18}$

14 Ruth Clark, op. cit., p. 55.

15 Ibid., p. 54.

16 Ibid., p. 57.

17 Ibid., p. 65.

18 Ibid., p. 192. 
Tal es el caso del Sindicato de Actores de la ciudad de México, liderado por los actores Roberto Soto y Leopoldo Ortín, el cual, por retirar su afiliación a la CROM tan pronto murió Álvaro Obregón en julio de 1928, sufrió boicots y atentados en los diferentes teatros donde presentaban sus funciones.

Según Marjorie Ruth Clark, en su libro La organización obrera en México, el evento que precipitó los conflictos entre la CROM y el presidente interino designado por Calles, Emilio Portes Gil, fue la defensa que éste hizo del sindicato de actores, al proporcionar tropas federales para resguardar el teatro donde presentaban sus obras y de este modo evitar algún ataque por elementos de la CROM. Portes Gil retiró por completo el apoyo incondicional del gobierno a la Confederación y utilizó todos sus medios para debilitarla. ${ }^{19}$

Roberto Soto explotaba su ligero parecido a Morones, satirizándolo en obras como Desmoronamiento, por lo cual fue aún más perseguido. ${ }^{20}$ En una de las imágenes tomadas por Aurelio Escobar podemos ver la compañía de actores de Roberto Soto, ya fuera de la CROM, en una de sus temporadas en Bellas Artes.

La desacreditación y pérdida de poder de la CROM impulsó a la gran mayoría de los sindicatos integrantes y los pocos que se habían mantenido al margen, a buscar una reorganización del movimiento obrero mexicano. A principios de 1930 se constituyó el Comité Pro Unificación Obrera y Campesina, formado por estos sindicatos y la Cámara Nacional del Trabajo. ${ }^{21}$

En este periodo surgió uno de los líderes más importantes de la historia del sindicalismo en México: Vicente Lombardo Toledano, quien a partir de su separación de la CROM y de la creación de la Confederación General de Obreros y Campesinos de México (CGOCM) entró en el ámbito sindical y constituyó uno de los pilares fundamentales para la política cardenista y la creación de la CTM.

19 Ibid., p. 111.

20 Ibid., p. 114.

21 Reyna, José Luis, et al., Tres estudios sobre el movimiento obrero en México, México, El Colegio de México, 1976, p. 40. 


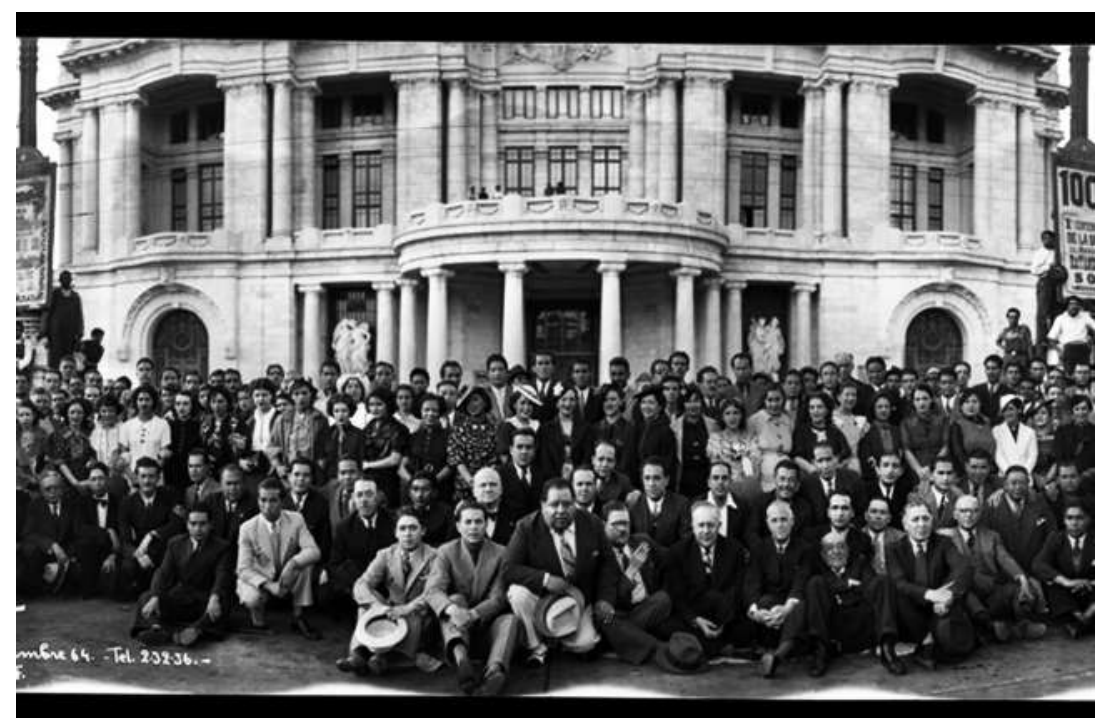

“Compañía Roberto Soto, Temporada en Bellas Artes", junio de 1937. (Detalle). AGN, AEC/01/136, 136.

\section{El cardenismo y la CTM}

Al tomar Lázaro Cárdenas la presidencia en 1934, también asumió la responsabilidad de reencauzar el movimiento obrero y campesino de México como un apoyo a su gobierno, tal y como la CROM lo fue para el maximato. ${ }^{22}$ La política de Cárdenas apeló sobre todo a la confianza y simpatía de las masas; su relación directa con obreros y campesinos le permitió la unificación de estos sectores y el apoyo necesario para la industrialización del país.

En 1935 surgió el Comité Nacional de Defensa Proletaria, en primer lugar para reunir a importantes sectores del proletariado y como reacción a las declaraciones hechas por Plutarco Elías Calles el 11 de junio del mismo año en relación con la "familia revolucionaria". Por otra parte, fue un excelente organismo para apoyar a Cárdenas, quien representaba la clave del triunfo del movimiento obrero. ${ }^{23}$

22 Anguiano, El Estado y la política obrera del cardenismo, p. 50.

23 León Sánchez, Constitución de la Confederación de Trabajadores Mexicanos. En el cincuentenario de su formación, México, p. 13. 


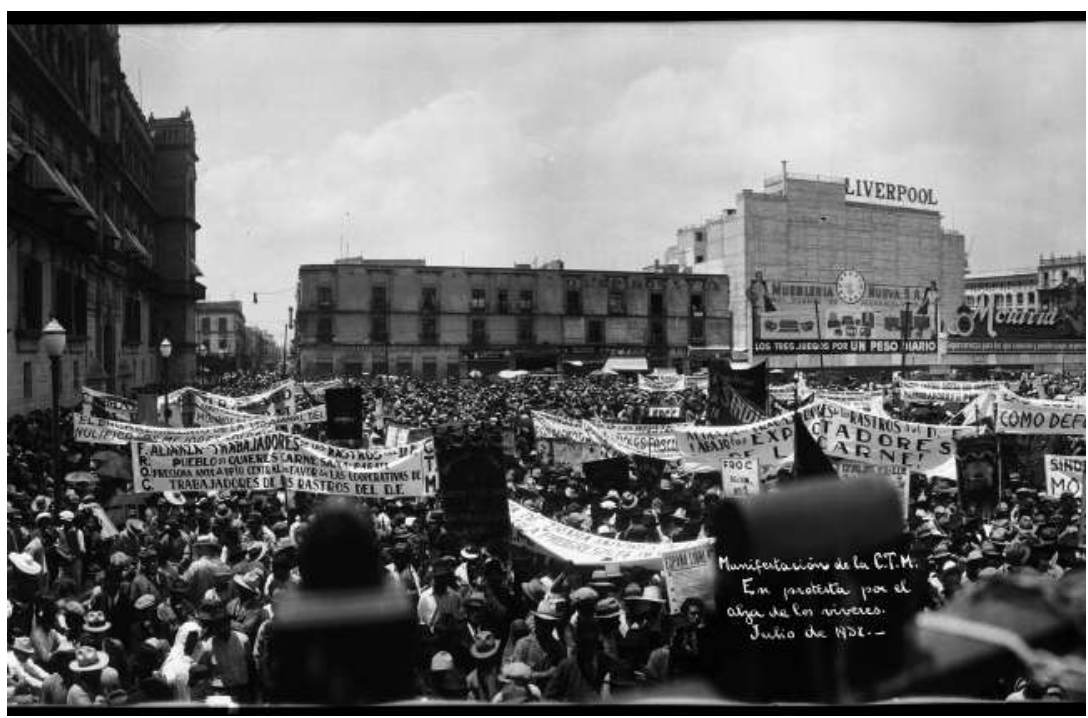

"Manifestación de la CTM (en protesta) por el alza de víveres", julio 1937. (Detalle). AGN, AEC/04/023, 1271.

En el congreso constituyente efectuado del 21 al 25 de febrero de 1936 surgió la Confederación de Trabajadores de México, donde se fusionaron sindicatos de industria y sindicatos de empresa, integrándose en federaciones regionales, locales y estatales que la convirtieron en la organización obrera más importante del país, por supuesto, bajo el apoyo de Cárdenas: “...la CTM dependería estrechamente de Cárdenas y se convertiría en uno de los pilares de la política de masas y el instrumento mediante el cual las masas de trabajadores serían movilizadas en apoyo de las decisiones del estado y en defensa del régimen establecido". ${ }^{24}$

Una de las numerosas actividades de la CTM, como la más importante central de unificación sindical, fue la organización de "mítines controlados en favor de la clase obrera" que, por supuesto, no representaran un peligro a la ya de por sí comprometida situación económica del país.

De esta forma Lázaro Cárdenas subordinó el movimiento obrero a los

24 Ibid., p. 58. 


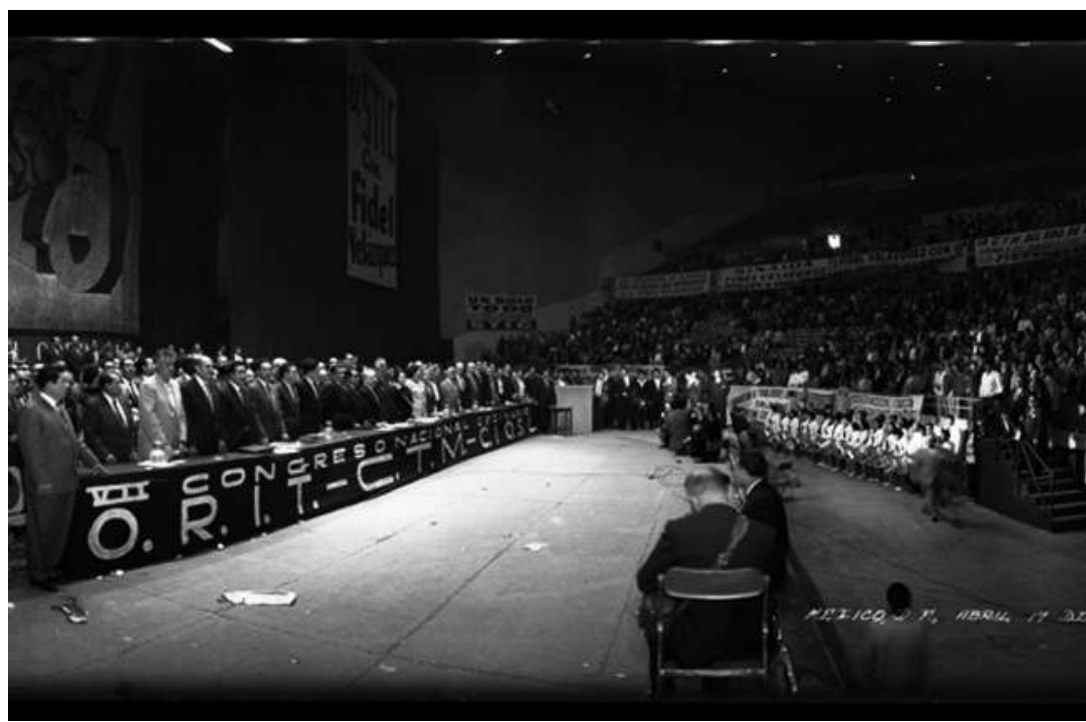

“VIII Congreso Nacional Ordinario ORIT-CTM-CIOSL”. AGN, AEC/30/015, 2736.

intereses del gobierno y la política, por medio de la CTM en manos de su secretario general, Vicente Lombardo Toledano, y de su secretario de organización y propaganda, Fidel Velázquez.

\section{La Segunda Guerra Mundial y la "estabilidad” política de México}

En 1941 Fidel Velázquez fue elegido nuevo secretario general de la CTM, donde permaneció en la dirección por más de 40 años, excepto de 1947 a 1950 periodo en que Fernando Amilpa ocupó el cargo. El discurso manejado por Fidel Velázquez en la dirección de la central fue el apoyo incondicional al gobierno.

La Segunda Guerra Mundial tuvo repercusiones tanto políticas como económicas para nuestro país, si bien México no tuvo una participación relevante en dicho conflicto. La política de Manuel Ávila Camacho fue de "unidad nacional y moderación", por la cual exigía a los sindicatos -a través de la CTM y el "Pacto de unidad obrera"- dejar a un lado sus intereses y buscar la unidad nacional mientras estuviera presente el conflicto armado. 
Esta situación significó el "despegue" en la industrialización del país y dio como resultado un régimen que favoreció la inversión privada sobre todo en el sector industrial, a costa de los intereses de la clase obrera.

Posteriormente, el gobierno de Miguel Alemán Valdés dio continuidad al crecimiento en el país de una gran desigualdad social y perpetuó en el poder al Partido Revolucionario Institucional, surgido en 1946. Desde sus inicios, su política fue totalmente antizquierdista; además, la СTM al mando de Fidel Velázquez fue un excelente instrumento de control y fraude, lo que originó la violación total de los derechos de los trabajadores.

La Guerra Fría tuvo como objetivo eliminar toda amenaza comunista o de izquierda en los países con influencia norteamericana, México entre ellos; tras este conflicto se creó la Alianza Obrera Campesina Mexicana a fines de 1947 y principios de 1948, la cual pactó a su vez con Luis Gómez Zetina y Valentín Campa, dirigentes de la Confederación Única de Trabajadores (CUT), quienes planearon reagrupar a los sindicatos escindidos de la CTM, bajo una organización de tintes comunistas.

Después de este periodo surgió el llamado "charrismo" sindical, refiriéndose con ello a la subordinación total de los líderes sindicales al Estado, en detrimento de las organizaciones laborales; los "charros" procuraron mantener fuera de ellas a los elementos considerados problemáticos por sus tintes "izquierdistas".

El "charrismo" remite a Jesús Díaz de León, alias "El charro", secretario general del Sindicato de Trabajadores Ferrocarrileros de la República Mexicana, quien en franca colaboración con el gobierno alemanista desplazó y traicionó a la antigua administración a cargo de Luis Gómez Z. y Valentín Campa, encarcelados por abuso de confianza en el manejo de los fondos sindicales. Al sustituir a las organizaciones sindicales populares por organizaciones charras el gobierno perdió contacto real con el pueblo y volvió ilegítimas y corruptas a éstas. ${ }^{25}$

El uso de líderes como elementos de control por parte del Estado, la despolitización de las masas, la desigualdad entre los sectores de la población, el desarrollo económico dependiente de la inversión extranjera y la política

25 Durant Ponte, La ruptura de la nación. Historia del movimiento obrero mexicano desde 1938 hasta 1952, p. 213. 
en contra de la izquierda y de los movimientos populares, frenaron todos los intentos por crear una central que reuniera a confederaciones y sindicatos en la lucha verdadera por el mejoramiento de la vida laboral de nuestro país, incapacidad organizativa que aún afecta a la clase obrera.

\section{Conclusiones}

Como se ha visto, la lente de Aurelio Escobar estuvo presente para inmortalizar un sinnúmero de organizaciones obreras, así como la lucha de éstas por lograr los derechos laborales fundamentales, además de los acontecimientos que jugaron un papel determinante. Espero que este trabajo marque la pauta para futuras investigaciones sobre el Fondo Aurelio Escobar, testimonio invaluable para la investigación y comprensión del sindicalismo en nuestro país. 


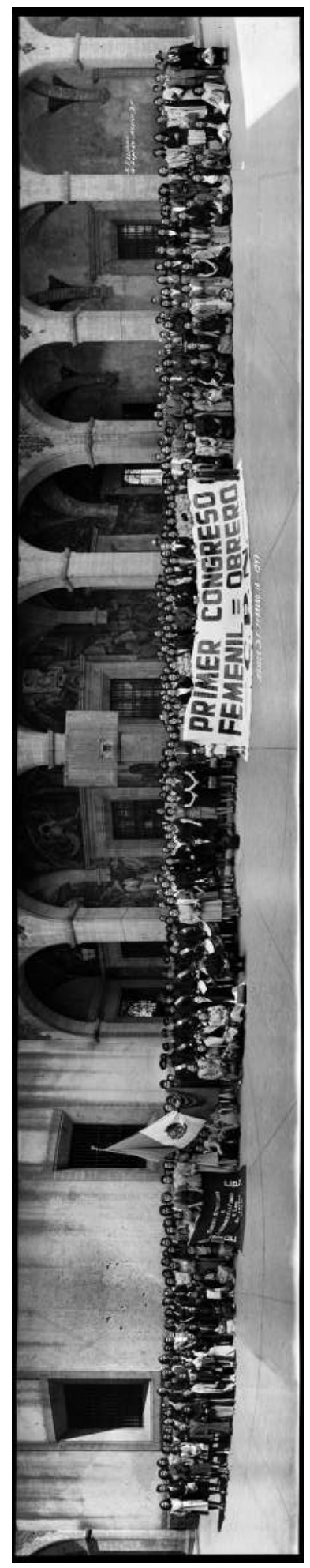

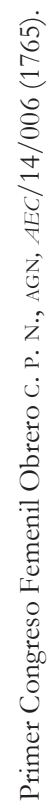

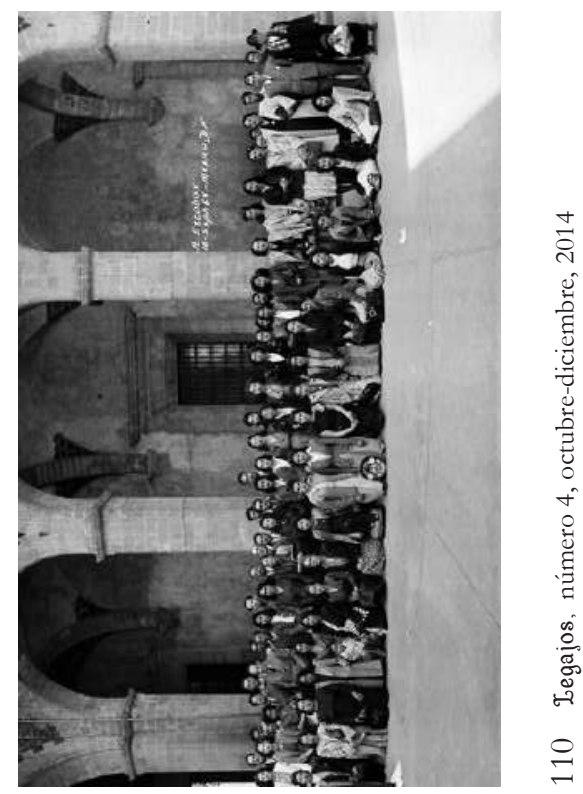



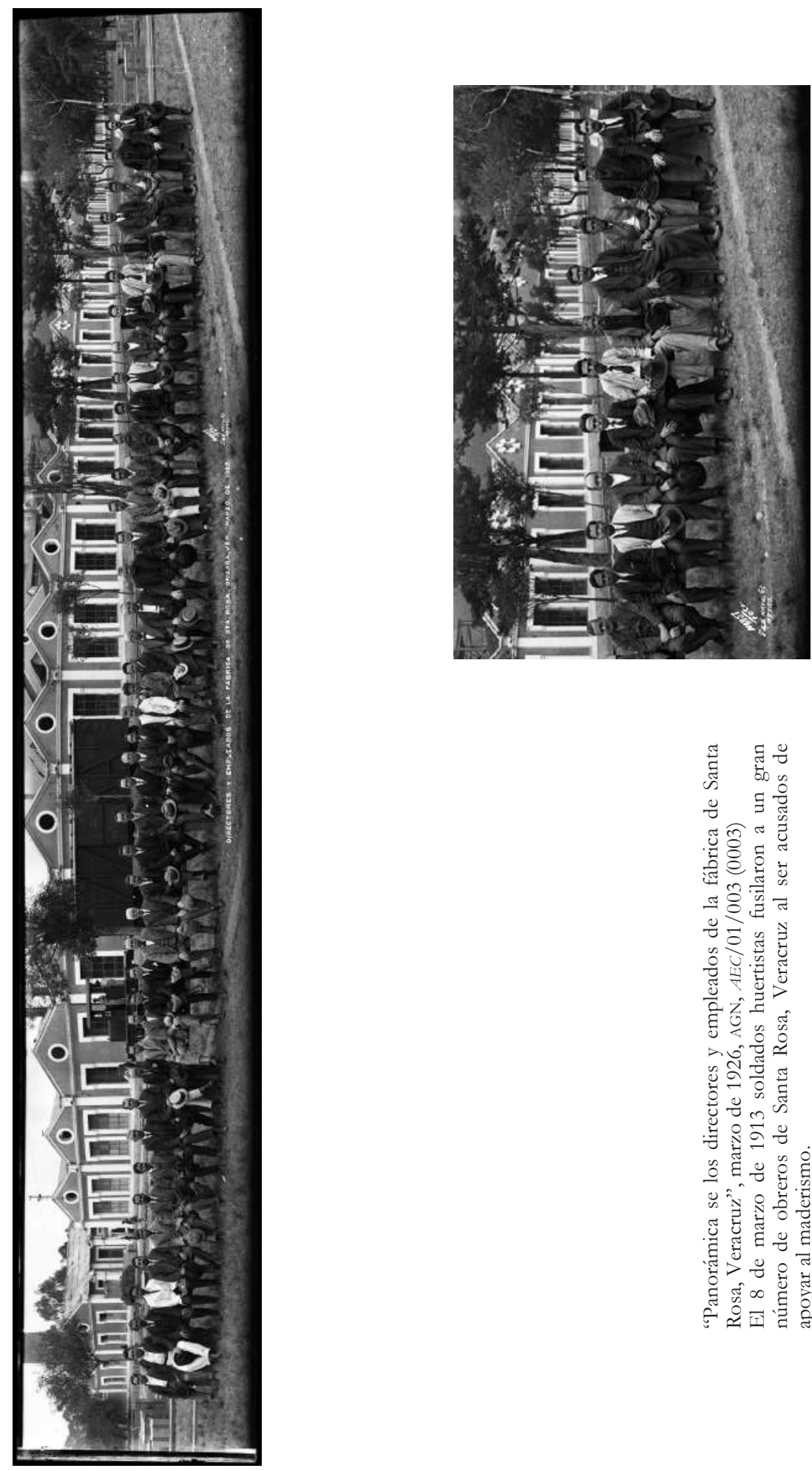

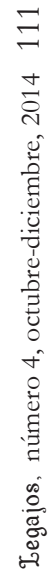

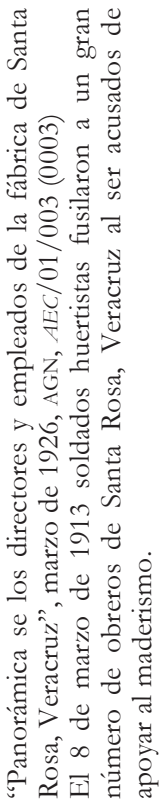



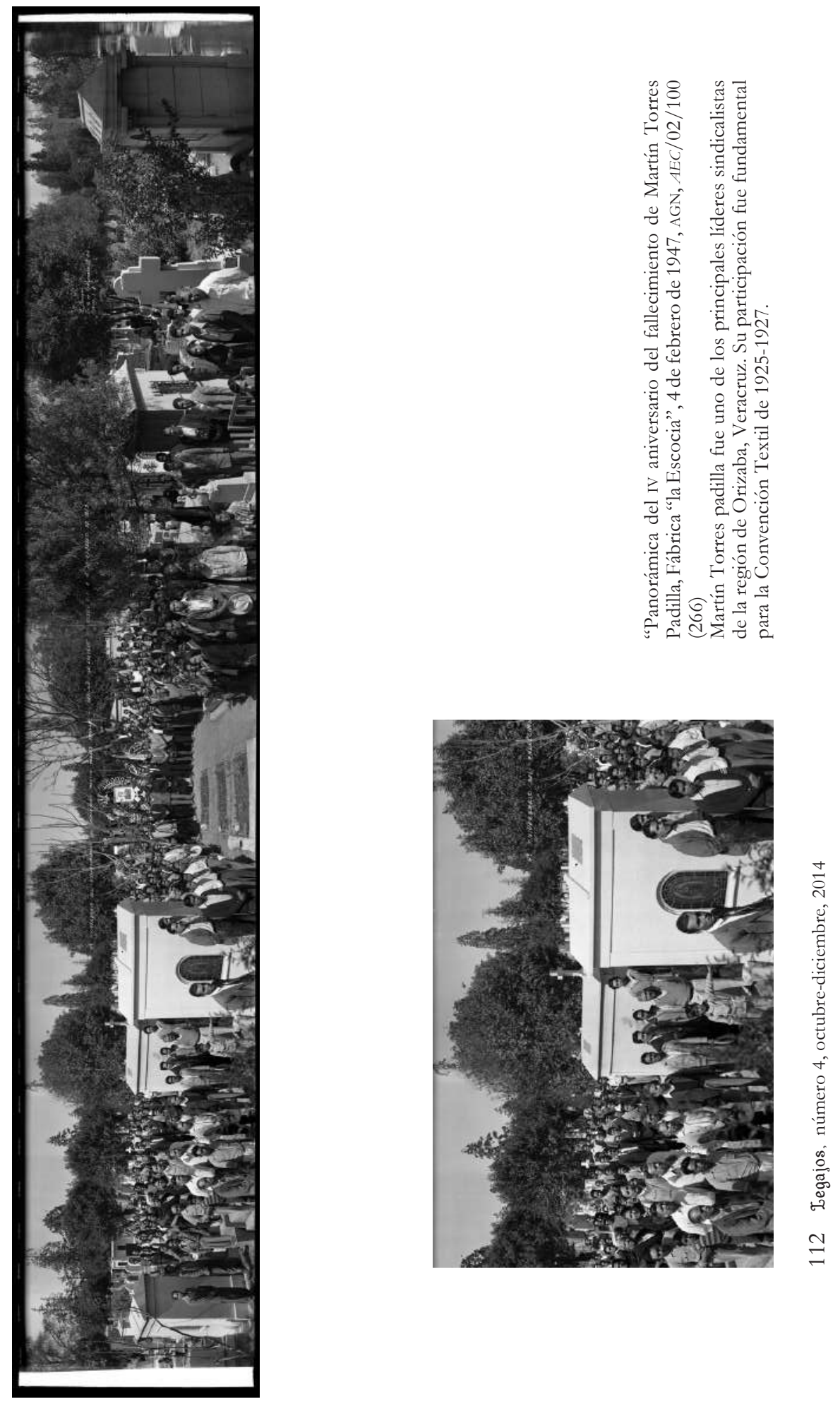

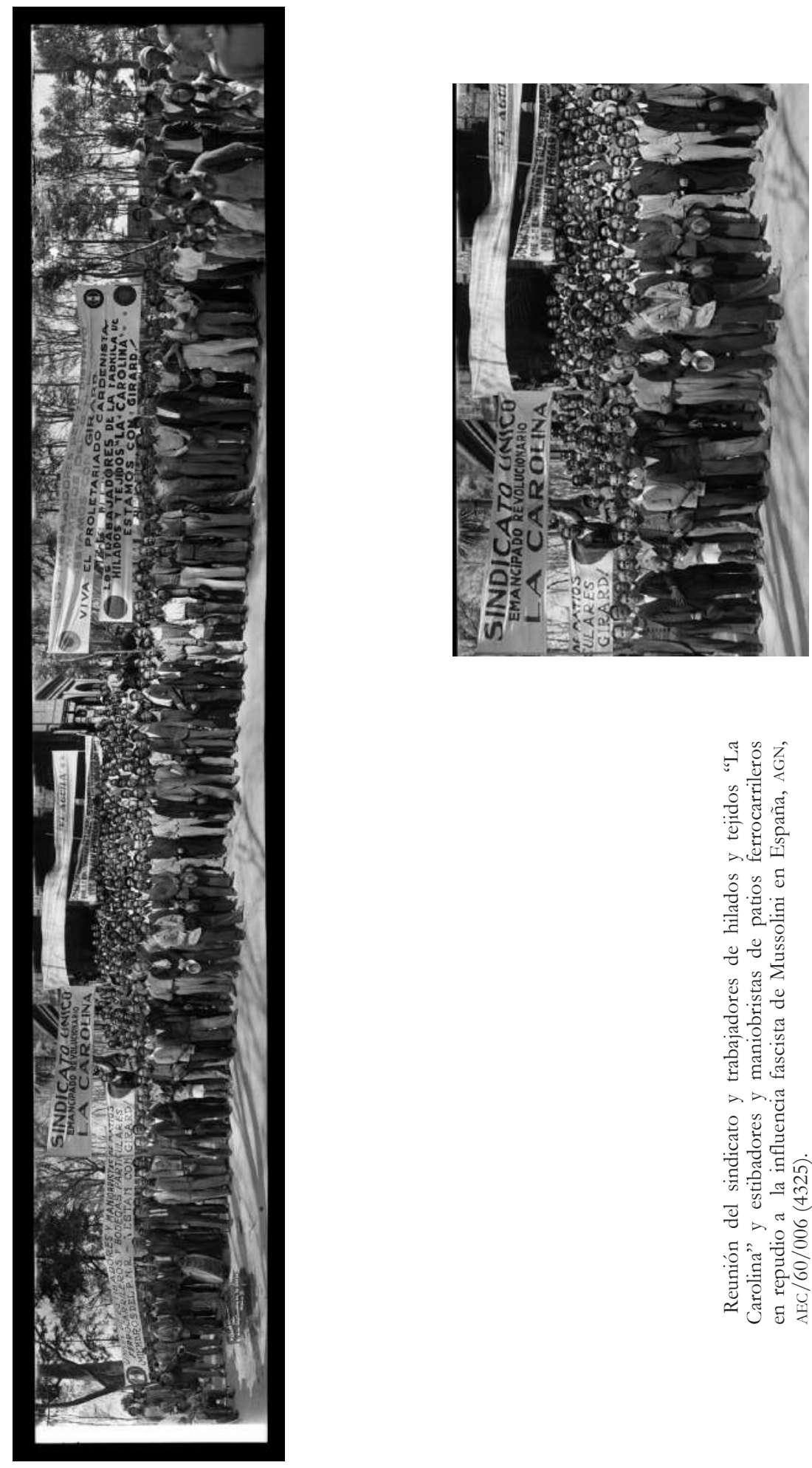

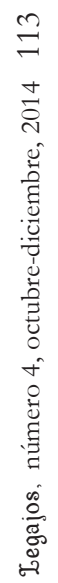

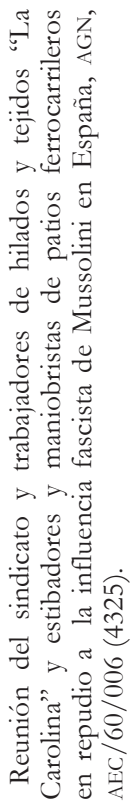



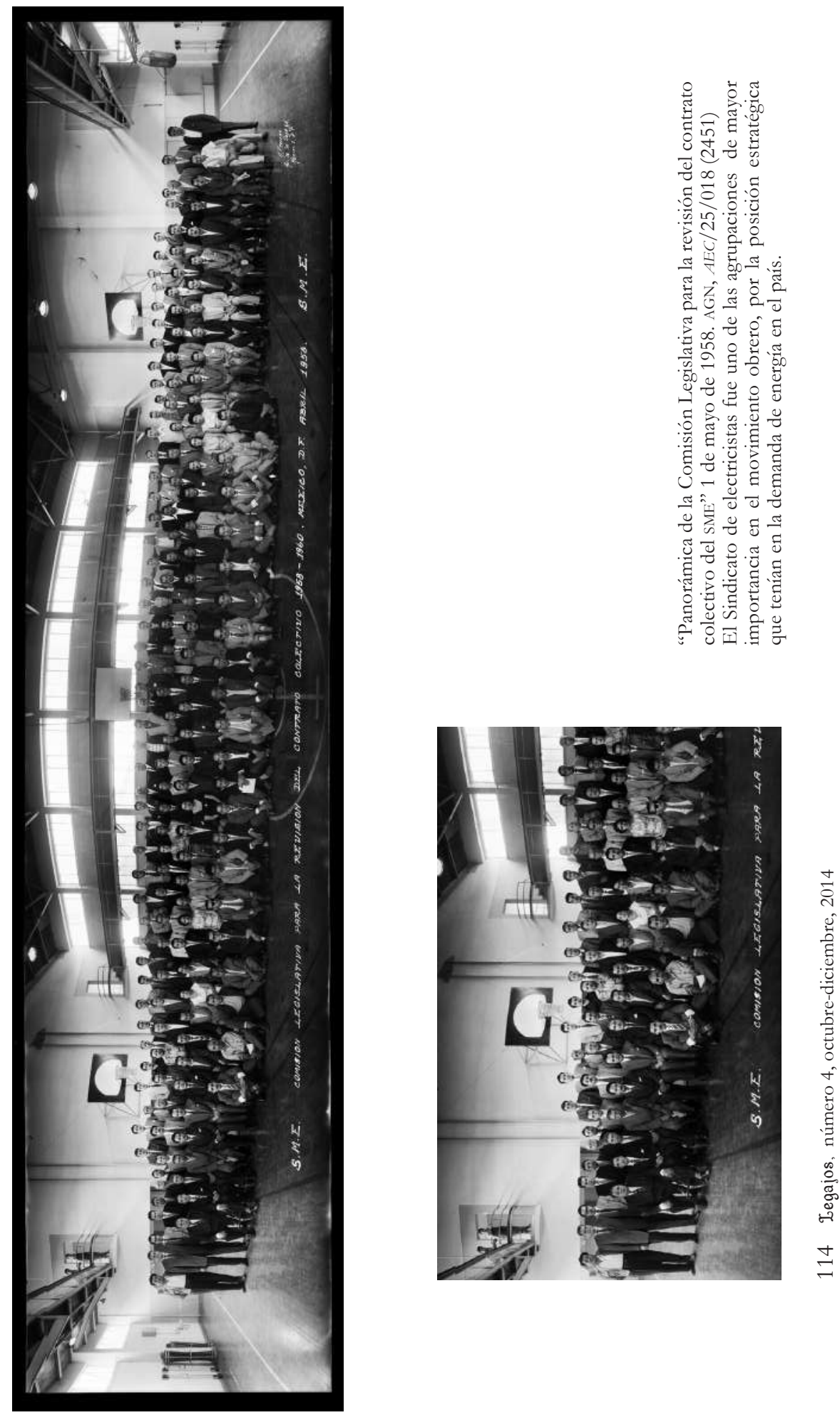

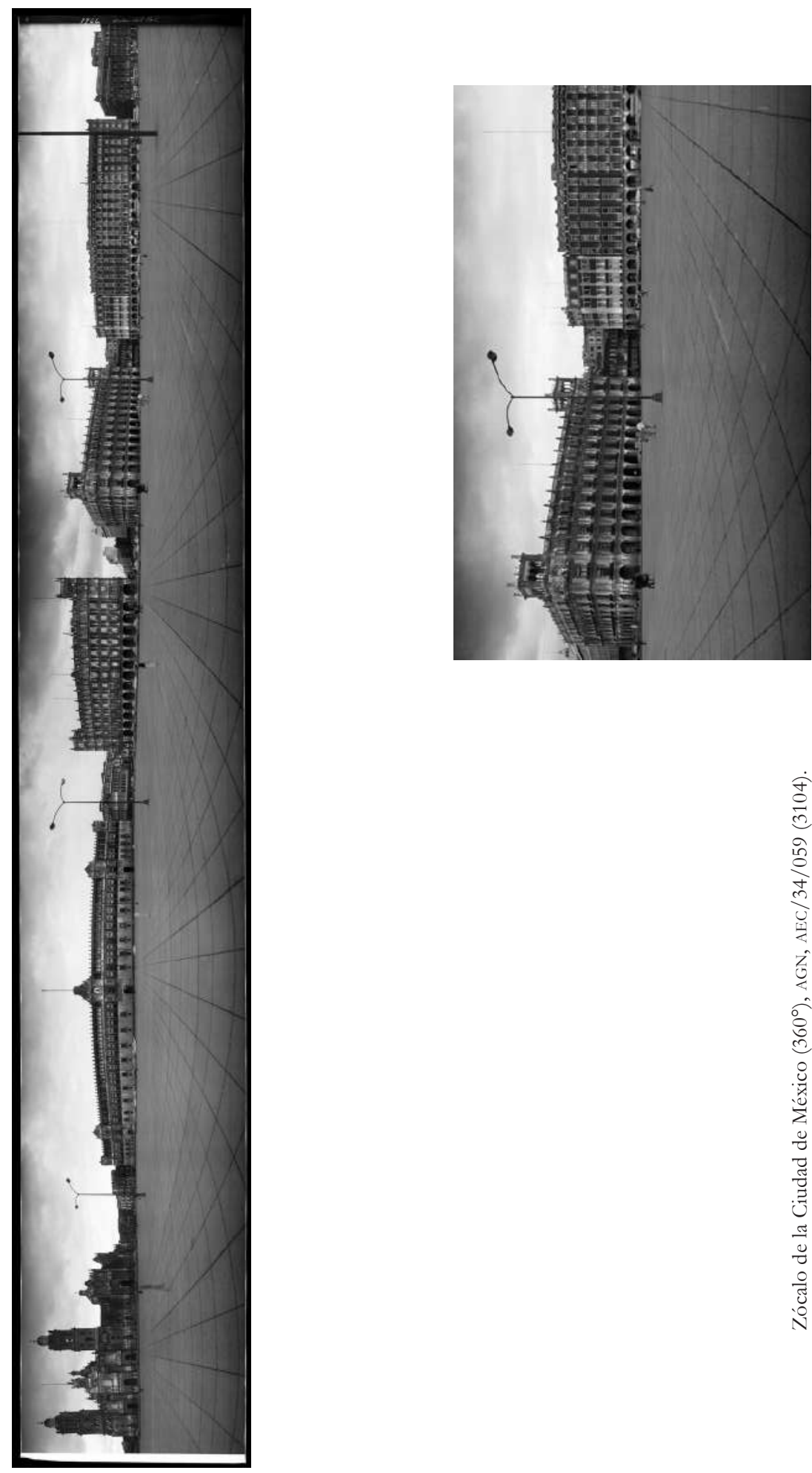

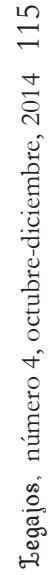

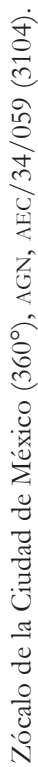




\section{Fuentes consultadas}

Archivo General de la Nación, Fototeca, Fondo Aurelio Escobar Castellanos.

Anguiano, Arturo, El Estado y la política obrera del cardenismo, México, ERA, México, 1980.

Aurelio Escobar Castellanos en http://es.wikipedia.org/wiki/Aurelio_ Escobar_Castellanos, [consulta 19 de octubre de 2011].

Durant Ponte, Víctor Manuel, La ruptura de la nación. Historia del movimiento obrero mexicano desde 1938 hasta 1952, México, UnAM, 1986.

Guevara Escobar, Arturo, “H. J. Gutiérrez, Foto”, en Fotógrafos de la revolución, http:// fotografosdelarevolución.blogspot.mx/2010/11/h-j-gutiérrezfoto.html, [consulta 19 de septiembre de 2012].

León Sánchez, Samuel, (comp.), Constitución de la Confederación de Trabajadores Mexicanos. En el cincuentenario de su formación, México, INEHRM, 1986.

Monroy Nasr, Rebeca, Ezequiel Carrasco, Entre los nitratos de plata y las balas de bronce, México, Instituto Nacional de Antropología e Historia, Sinafo, Conaculta, 2011.

Montellano Ballesteros, Francisco, Charles B. Waite, La época de oro de las postales en México, México, Círculo de Arte, 1998.

Reyna, José Luis, et al., Tres estudios sobre el movimiento obrero en México, México, El Colegio de México, 1976.

Ribera Carbó, Anna, La Casa del Obrero Mundial. Anarcosindicalismo y revolución en México, México, Instituto Nacional de Antropología e Historia, 2010. Ruth Clark, Marjorie, La organización obrera en México, México, Era, 1979. 